ISSN: 1858-4837; E-ISSN: 2598-019X

Volume 17, Nomor 1 (2022),

https://jurnal.uns.ac.id/region

DOI: 10.20961/region.v1711.41465

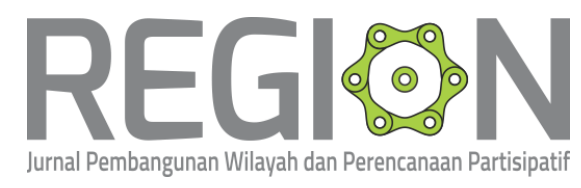

\title{
Dampak kepariwisataan terhadap perubahan pola urbanisasi di Indonesia
}

\section{Tourism impact on changing pattern of urbanization in Indonesia}

\author{
A R J Nabal ${ }^{1}$, K Djaja $^{1}$ \\ ${ }^{1}$ Program Studi Kajian Pengembangan Perkotaan, Sekolah Kajian Stratejik dan Global, \\ Universitas Indonesia
}

Corresponding author's email: alfred.rodriques@ui.ac.id

\begin{abstract}
Abstrak. Indonesia memasuki era perkotaan, ditandai oleh dominannya proporsi penduduk yang tinggal di kota. Urbanisasi memberi dampak bagi pertumbuhan ekonomi dan kelayakan hidup orang Indonesia. Namun, urbanisasi juga menciptakan kesenjangan pembangunan antar-wilayah serta munculnya masalah kemiskinan dan kekumuhan. Di tengah paradoks urbanisasi ini, kepariwisataan muncul sebagai penggerak utama pembangunan di Indonesia. Penelitian ini bertujuan untuk menjelaskan dampak kepariwisataan terhadap perubahan pola urbanisasi di Indonesia. Penelitian menggunakan metode kualitatif dengan model deskriptifanalitik. Pengumpulan data dan informasi melalui studi literatur. Hasil penelitian menunjukkan pergeseran paradigma, strategi pengembangan, dan pola pengelolaan pariwisata di Indonesia mengubah corak urbanisasi dalam dua pola. Pertama, munculnya pola urbanisasi yang mengubah desa menjadi daerah yang memiliki ciri perkotaan karena pengembangan pariwisata perdesaan. Kedua, berkembangnya kotakota kecil, sedang, dan kota-kota (daerah urban) baru karena tren wisata kota. Kedua pola ini menciptakan urbanisasi yang proporsional dan berkontribusi dalam agenda pemerataan pembangunan di Indonesia.
\end{abstract}

Kata Kunci: Kepariwisataan; Kesenjangan dan Ketimpangan; Pariwisata Perdesaan; Urbanisasi; Wisata Kota

Abstract. Indonesia entered the urban era marked by the dominant proportion of the population living in cities. Urbanization has an impact on economic growth and the well-being of Indonesia society. However, urbanization also creates inter-regional 
development gaps and the emergence of poverty and slum. Amid this urbanization paradox, tourism emerged as the prime mover of development in Indonesia. This study aims to explain the impact of tourism on changing patterns of urbanization in Indonesia. This research employed qualitative method with a descriptive-analytic model. Data and information collection is through literature studies. The results showed that paradigm shifts, development strategies, and patterns of tourism management in Indonesia changed the urbanization style into two models. First, the emergence of urbanization patterns that have transformed villages into areas that have urban characteristics due to the development of rural tourism. Second, the development of the small, medium, and new cities (urban areas) due to urban tourism trends. These two models create proportional urbanization and contribute to the agenda of equitable development in Indonesia.

Keywords: City Tour; Gaps and Inequality; Rural Tourism; Tourism; Urbanization

\section{Pendahuluan}

Urbanisasi telah banyak mengubah wajah Indonesia. Bahkan, proyeksi urbanisasi di masa mendatang akan secara signifikan mentransformasi Indonesia sebagai negara yang sebagian besar masyarakatnya hidup di kawasan perkotaan. Di tahun 1945, penduduk Indonesia yang hidup di perkotaan hanya 10 persen, kemudian meningkat menjadi 56 persen saat ini dan diproyeksikan lebih dari 70-an persen di tahun 2045 [1]. Dari segi Produk Domestik Bruto (PDB), urbanisasi telah meningkatkan PDB per kapita. Tingkat standar hidup layak di Indonesia pun jauh lebih tinggi dibandingkan sebelumnya. Perkembangan urbanisasi seperti ini memberikan banyak dampak positif bagi kehidupan masyarakat Indonesia [2].

Namun, di tengah urbanisasi yang signifikan, agenda kesejahteraan masyarakat di Indonesia tidak serta merta terwujud. Indonesia masih berada di bawah negara-negara berkembang lain dengan laju urbanisasi yang tipikal seperti di Indonesia. Bahkan, urbanisasi turut menciptakan kesenjangan pembangunan di Indonesia. Wilayah Jawa yang mengalami tingkat urbanisasi tinggi dibandingkan wilayah lainnya mendominasi pertumbuhan ekonomi nasional sebesar 59 persen pada tahun 2019 [3]. Persoalan lainnya adalah fenomena kemiskinan dan berkembangnya kawasan kumuh di perkotaan [4]. Urbanisasi di Indonesia belum mampu menghadirkan kesejahteraan dan mewujudkan pemerataan pembangunan.

Kepariwisataan menunjukkan tren positif di tengah kebuntuan agenda urbanisasi di Indonesia. Indonesia telah mulai mengembangkan industri pariwisata sejak akhir tahun 1960-an. Tetapi menjelang akhir abad-20, pariwisata belum menunjukkan dampak bagi kesejahteraan masyarakat dan pemerataan pembangunan. Memasuki abad ke-21, di mana paradigma kepariwisataan bergeser, pariwisata Indonesia menunjukkan perkembangan yang signifikan. Pariwisata menjadi sektor inklusif yang memungkinkan masyarakat menjadi subjek pembangunan [5]. Kepariwisataan berkembang di banyak daerah di Indonesia. Dalam Rencana Induk Pembangunan Kepariwisataan Nasional, Indonesia menetapkan 88 Kawasan Strategis Pariwisata Nasional yang tersebar di banyak daerah. Perkembangan Kepariwisataan 
Indonesia sebagai instrumen pembangunan nasional ini memiliki garansi dalam mengatasi kebuntuan urbanisasi dan menginisiasi pola baru urbanisasi di Indonesia kedepannya.

\section{Metode}

Penelitian ini menggunakan metode kualitatif dengan model deskriptif-analitik. Model deskriptif analitis adalah salah satu model dalam penelitian kualitatif yang berfungsi mendeskripsikan atau memberi gambaran terhadap objek yang diteliti [6]. Penelusuran literatur digunakan untuk mendapatkan data dan informasi sebagai basis dalam menjelaskan pola urbanisasi di Indonesia, kebuntuan urbanisasi di Indonesia, dan potensi pengembangan pariwisata yang menghadirkan pola urbanisasi secara proporsional. Analisis mencakup beberapa poin. Pertama, mengulas konsep multidimensional urbanisasi sebagai basis untuk memahami urbanisasi. Kedua, mengulas perkembangan urbanisasi di Indonesia dan mengidentifikasi persoalan urbanisasi hari ini. Penjelasan tentang perkembangan urbanisasi di Indonesia penting untuk memahami bagaimana posisi kota di Indonesia dalam agenda pembangunan negara dari waktu ke waktu. Ketiga, menganalisis trayektori kepariwisataan Indonesia untuk mengetahui perkembangan pariwisata Indonesia dari waktu ke waktu. Keempat, membahas dinamika kepariwisataan sebagai jalan keluar dari kebuntuan urbanisasi. Bagian ini akan menunjukkan kepariwisataan sebagai penggerak utama agenda urbanisasi di Indonesia kedepannya.

\section{Hasil penelitian dan pembahasan}

\subsection{Urbanisasi sebagai konsep multidimensional}

Urbanisasi secara klasik dipahami sebagai perpindahan manusia dari desa menuju kota. Perpindahan ini dipicu oleh faktor daya tarik kota dan daya dorong desa. Daya tarik kota meliputi banyak faktor seperti ketersediaan lapangan pekerjaan, ketersediaan sarana dan prasarana penunjang kehidupan, ketersediaan ruang berekspresi, ketersediaan instrumen untuk mewujudkan mimpi, dan ketersediaan lembaga pendidikan. Sedangkan daya dorong desa adalah negasi dari faktor daya tarik kota.

Dinamika permukiman kemudian semakin kompleks akibat banyaknya faktor yang saling bertemu, mempengaruhi satu sama lain, dan mengubah pola-pola kehidupan permukiman. Faktor-faktor ini mencakup aspek sosial, ekonomi, politik, ideologi, dan nilai-nilai. Interaksi faktor-faktor ini mengakibatkan kehidupan permukiman sangat dinamis. Untuk menjelaskan dinamika perkotaan yang kompleks ini, diperlukan suatu prinsip umum yang menjadi dasar untuk menganalisis berbagai masalah permukiman dan mencari solusi atas masalah-masalah tersebut. Urbanisasi kemudian berkembang menjadi konsep yang multidimensional dan menjadi dasar untuk menjelaskan kompleksitas dinamika perkotaan.

Poungsomlee \& Ross dalam Keban [7] mendefinisikan urbanisasi menggunakan pendekatan demografis, ekonomi-politik, dan modernisasi. Secara demografis, urbanisasi berarti peningkatan konsentrasi penduduk di daerah perkotaan. Secara ekonomi-politik, urbanisasi merujuk pada transformasi ekonomi-politik akibat ekspansi kapitalisme. Untuk pendekatan modernisasi, urbanisasi merupakan proses perubahan orientasi tradisional menjadi orientasi 
modern karena adanya difusi modal, teknologi, nilai-nilai, dan kepentingan dari masyarakat modern ke masyarakat tradisional. Kemudian, Harjoko dalam Harahap [8] menjelaskan urbanisasi sebagai proses perubahan permukiman masyarakat dari wilayah non-urban menjadi urban. Perubahan ini terjadi akibat diferensiasi dan spesialisasi pemanfaatan ruang dalam wilayah tersebut.

Damsar dan Indrayani [9] mendefinisikan urbanisasi ke dalam empat poin. Pertama, urbanisasi sebagai proses migrasi manusia/penduduk dari desa ke kota sehingga menyebabkan pertumbuhan populasi di kawasan perkotaan. Kedua, urbanisasi merupakan proses perkembangan infrastruktur ekonomi dan suprastruktur sosial-budaya dan politik suatu daerah sehingga menjadi lebih heterogen dan kompleks. Akibatnya, daerah tersebut menunjukkan ciri perkotaan. Ketiga, urbanisasi dilihat sebagai pertumbuhan penduduk suatu kawasan perdesaan karena faktor kelahiran, kemudian diikuti perkembangan infrastruktur ekonomi dan pembagian kerja yang heterogen. Kawasan perdesaan ini kemudian memiliki ciri perkotaan. Ke empat, urbanisasi sebagai proses pengaruh infrastruktur ekonomi dan suprastruktur sosial-budaya dan politik perkotaan terhadap perdesaan melalui hubungan kota-desa.

Beberapa pandangan tentang urbanisasi ini hendak menjelaskan urbanisasi sebagai proses sesuatu menjadi atau bersama perkotaan melalui pertumbuhan populasi, pengaruh atau perkembangan infrastruktur ekonomi, dan suprastruktur sosial-budaya dan politik. Sebagai konsep yang multidimensional, urbanisasi perlu dilihat melalui pendekatan demografi, proses ekonomi-politik, dan bagian dari modernisasi. Determinan utama terjadinya urbanisasi adalah peningkatan kelayakan dan kesejahteraan hidup. Pergerakan manusia dari desa menuju kota maupun adanya transformasi wilayah menjadi daerah perkotaan dipicu oleh upaya manusia untuk mencapai kelayakan dan kesejahteraan.

\subsection{Perkembangan urbanisasi di Indonesia}

Awal mula urbanisasi di Indonesia dapat dijelaskan melalui pendapat Paul Wheatley [10] tentang urban genesis dalam karyanya berjudul Nagara and Commandery. Wheatley membagi proses terbentuknya perkotaan (urban genesis) menjadi dua. Pertama disebut dengan urban generation, yaitu integrasi sosial-budaya yang terjadi karena menyatunya budaya masyarakat setempat dengan budaya masyarakat pendatang dalam suatu wilayah tanpa melalui paksaan. Proses penyatuan ini terjadi secara evolutif. Kedua disebut dengan urban imposition, yaitu proses integrasi sosial-budaya dalam masyarakat yang cenderung dipaksakan karena kekuatan kolonial yang mengatur sistem dan organisasi dalam masyarakat.

Jauh sebelum terbentuknya negara Indonesia, habitat komunitas mandiri telah ada dan berkembang di wilayah nusantara. Komunitas ini berasal dari Yunan, China Selatan yang melakukan migrasi masuk ke wilayah Nusantara tahun 1200 SM. Setelah itu, orang-orang Deutro Melayu juga melakukan migrasi ke wilayah Nusantara dan membentuk pranatanya sendiri di tahun 300 SM. Kepemimpinan dan sistem yang dibangun oleh komunitas-komunitas tersebut sepenuhnya diatur oleh mereka sendiri [11]. Paul Wheatley mengidentifikasi komunitas mandiri tersebut sebagai chiefdom. Komunitas mandiri ini disebut dengan 
desa/mukiman adat dan ditemukan di beberapa tempat di Indonesia. Beberapa diantaranya adalah desa adat Bawomataluo di Nias; Tondok, Tongkonan, dan Banua di Toraja; serta Mukiman Megalitikum di Sumba.

Setelah komunitas mandiri ini bertahan cukup lama, suatu komunitas yang lebih kompleks muncul di Nusantara dalam bentuk kerajaan. Terdapat dua fase kemunculan kerajaan ini. Fase pertama, munculnya kerajaan-kerajaan Hindu-Buddha sejak abad ke 2 Masehi yang mendapat pengaruh dari India [11]. Pada fase ini, integrasi sosial-budaya terjadi antara budaya komunitas yang telah ada dengan budaya baru yang mendapat pengaruh dari India. Hasil dari integrasi ini adalah suatu pranata yang lebih kompleks yang ditandai dengan pemimpin yang disebut raja, mempunyai aturan, birokrasi, dan bala tentara. Fase kedua terjadi pada abad ke 15 Masehi yang ditandai dengan perubahan dari kerajaan menuju kesultanan Islam [11]. Perubahan ini terjadi secara evolutif yang dilakukan melalui jalur perdagangan dan siar agama. Kehadiran kerajaan dan kesultanan ini dikategorikan sebagai urban generation atau kebangkitan perkotaan. Habitat manusia yang disebut kota telah terbentuk dan menjadi ibukota kerajaan dan kesultanan. Kota-kota tersebut telah menjadi pusat perdagangan dan pemerintahan.

Kehadiran bangsa Eropa ke wilayah Nusantara sejak abad ke 16 turut mempengaruhi terbentuknya perkotaan. Dimulai dengan keberadaan VOC yang mengendalikan kota sebagai pusat kekuasaan serta pengendalian dagang dan keamanan. Sebagai pusat kekuasaan, VOC membangun Kota Jakarta (sebelumnya Batavia). Sebagai pusat pengendalian sumber rempah, VOC melakukan ekspansi ke Ambon, Ternate, Tidore, Banda, dan di Nusa Tenggara [11]. Untuk pusat perdagangan, VOC mengendalikan Surabaya, Semarang, dan Makasar. Setelah kekuasaan VOC berakhir pada akhir abad ke-18, Pemerintah Belanda mengambil alih wilayah kekuasaan di Nusantara yang dikenal dengan sebutan Hindia Belanda. Kota-kota berkembang secara signifikan sebagai pusat pemerintahan, bisnis, perdagangan, dan industri [11]. Fungsifungsi kota ini dilatarbelakangi oleh persaingan negara-negara di Eropa dalam hal perebutan wilayah untuk mengakumulasi keuntungan ekonomi mereka. Kota-kota di Hindia Belanda menjadi pusat industri dan perdagangan untuk kepentingan ekonomi negara penjajah. Pada periode abad ke-16 sampai awal abad ke-20, perkembangan kota-kota di Hindia Belanda ditentukan oleh pengaruh kolonialisme yang memaksakan sistemnya atas wilayah yang dikuasai. Banyak kota-kota yang dihasilkan melalui urban imposition.

Pada pertengahan abad ke-20, Indonesia menjadi negara merdeka. Kota-kota yang ada diwariskan oleh kolonialisme Belanda. Ada juga perkotaan yang diwariskan dari periode kerajaan dan kesultanan, namun tidak banyak. Perkotaan sejak masa awal kemerdekaan hingga saat ini mengalami perkembangan signifikan dengan kompleksitas peran yang dimilikinya. Perkotaan menjadi pusat politik dan administrasi pemerintahan, bisnis, perdagangan, industri, wahana, dan globalisasi. Jumlah kota di Indonesia bertambah dari waktu ke waktu. Pada masa awal kemerdekaan kota di Indonesia yang berstatus otonom ada 32 kota. Saat ini Indonesia telah memiliki 98 kota otonom dan 416 kota sebagai ibu kota kabupaten. 
Pertambahan jumlah kota ini menunjukkan laju urbanisasi yang cepat di Indonesia. Keberadaan kota-kota ini memperbanyak konsentrasi penduduk untuk hidup di daerah perkotaan. Pada tahun 1945, hanya 8,6 juta orang (sekitar 10 persen dari total populasi) yang tinggal di perkotaan. Pada tahun 2020, penduduk yang tinggal di perkotaan akan mencapai 56,7 persen atau sekitar 151 juta orang. Antara kurun waktu 1945-2017 laju urbanisasi ini berjalan fluktuatif. Pada tahun 1950-1960, laju urbanisasi kurang dari dua persen. Laju paling signifikan terjadi antara tahun 1980 sampai 1990-an yang mencapai tiga persen lebih. Memasuki tahun 2000 sampai 2017, laju urbanisasi kembali ke angka satu persen lebih. Grafik yang menunjukkan laju urbanisasi Indonesia dalam perbandingannya dengan laju urbanisasi semua negara dapat ditinjau pada Gambar 2 [2].

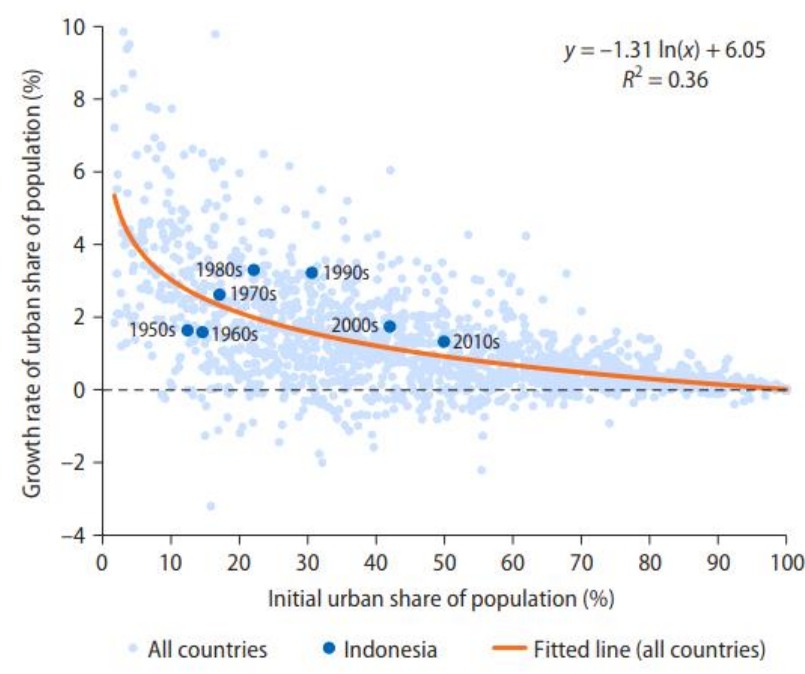

Gambar 1. Laju urbanisasi di Indonesia [2].

Laju urbanisasi ini berdampak terhadap peningkatan kesejahteraan masyarakat. Dampak kesejahteraan ini merupakan konsekuensi atas dijadikannya kota sebagai pusat industri, perdagangan, dan bisnis. Pemusatan orientasi ekonomi tersebut menciptakan faktor-faktor aglomerasi di perkotaan. Aglomerasi memungkinkan terjadinya inovasi dan peningkatan produktivitas. Dalam kawasan aglomerasi, masyarakat akan mudah dipertemukan dengan perusahaan yang mencari tenaga kerja, pertukaran ide dan pengetahuan akan terjadi secara cepat, dan akses-akses terhadap pasar lebih mudah dilakukan. Maka, kesempatan masyarakat untuk memperoleh kesejahteraan semakin besar sehingga negara mendapatkan pertumbuhan ekonomi yang besar pula. Sejak tahun 1949, Produk Domestik Bruto (PDB) per kapita meningkat sepuluh kali lipat [1].

Namun, dampak pertumbuhan ekonomi dan kesejahteraan masyarakat ini ternyata belum mencapai tingkat optimal jika dibandingkan dengan negara lainnya. Peningkatan PDB per kapita Indonesia masih rendah, yaitu hanya 1,4 persen. Bandingkan dengan PDB per kapita negara berkembang di Asia Timur dan Pasifik yang mencapai angka 2,7 persen, dua kali lipat dibanding dengan Indonesia. Grafik perbandingan PDB per kapita antara Indonesia dengan negara lainnya dari tahun 1996-2016 dapat ditinjau pada Gambar 2. 


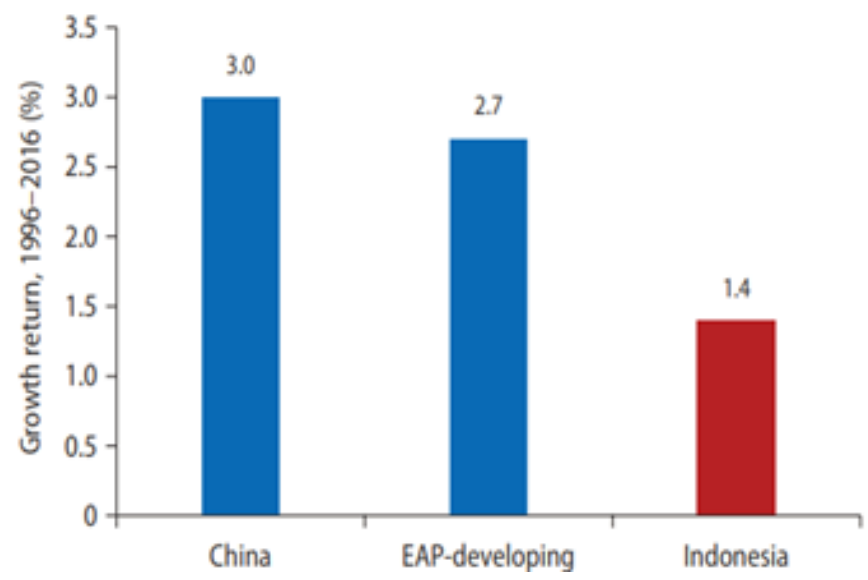

Gambar 2. Perbandingan peningkatan PDRB per kapita tahun 1996-2016 [2].

Persoalan lainnya adalah adalah tingginya tingkat kesenjangan di Indonesia. Disparitas antara penduduk miskin perkotaan dan non-perkotaan (desa) pada tahun 2017 adalah 10,6 juta orang berbanding 17,1 juta orang. Indikator lainnya adalah konsumsi riil per kapita antara penduduk desa dan penduduk kota yang perbedaannya masih tinggi. Pada tahun 2015 , jumlah konsumsi riil per kapita penduduk di desa 43 persen lebih rendah daripada penduduk di kota besar seperti Jakarta. Secara demografi, kesenjangan tampak pada tingginya konsentrasi penduduk hanya di kota-kota besar. Faktor-faktor produksi yang masih banyak terkonsentrasi di kota-kota besar menyebabkan urbanisasi terjadi secara tidak proporsional. Corak urbanisasi masih didominasi oleh faktor migrasi desa ke kota. Pekerja-pekerja terampil banyak berpindah ke kota, sedangkan desa menjadi kekurangan tenaga kerja terampil. Faktor pertumbuhan kota-kota besar di Indonesia disumbang oleh migrasi sebesar 20 persen [2].

Urbanisasi juga menjadi penyebab munculnya masyarakat miskin kota. Kota-kota besar yang telah ada saat ini memiliki kapasitas daya tampung yang terbatas. Selain itu, kompetisi yang tinggi di perkotaan mengharuskan masyarakat yang tinggal di perkotaan untuk memiliki spesialisasi dan keterampilan. Migrasi penduduk yang tidak didukung oleh keterampilan dan spesialisasi akan kalah dalam persaingan di perkotaan. Dampaknya adalah munculnya permukiman kumuh di perkotaan. Jakarta sebagai salah satu barometer perkotaan di Indonesia memiliki 445 RW kumuh [12]. Tantangan-tantangan ini semakin mengkhawatirkan jika melihat proyeksi jumlah penduduk perkotaan di Indonesia pada tahun 2045 berdasarkan laju urbanisasi saat ini. Lebih dari 70 persen penduduk Indonesia di usia 100 tahun Indonesia akan menempati wilayah perkotaan. Jika kebuntuan urbanisasi saat ini tidak diantisipasi, Indonesia akan terjebak dalam urbanisasi yang menciptakan kegagalan pembangunan; perkotaan menjadi tidak terkendali, dan ketimpangan antar wilayah akan semakin besar.

\subsection{Trayektori kepariwisataan di Indonesia}

Munculnya revolusi industri di Inggris pada abad ke-18 turut mempengaruhi perkembangan industri pariwisata di dunia. Keterkaitan keduanya dapat dipahami dalam dua hal. Pertama, revolusi industri memicu munculnya kesadaran orang untuk berwisata. Untuk menggantikan 
hiburan alkohol sebagai hiburan yang banal, berbagai tur dilakukan orang-orang di Inggris untuk bersenang-senang dan rekreasi hingga menjadi cikal bakal perjalanan keliling dunia untuk berwisata. Kedua, industri pariwisata membawa semangat revolusi industri yang berorientasi pada keuntungan ekonomi. Kesenangan orang untuk melakukan wisata memberikan peluang yang besar bagi pendapatan ekonomi bagi daerah yang dituju maupun orang atau kelompok yang mengatur perjalanan wisata [5].

Kesadaran berwisata dan potensi keuntungan ekonomi dalam industri pariwisata ini mempengaruhi geliat kepariwisataan di Indonesia. Permulaan munculnya dapat dilacak sejak akhir tahun 1960-an. Ketika itu, pemerintah Indonesia menjadikan sektor pariwisata sebagai salah satu instrumen pembangunan nasional. Hal tersebut tertuang dalam Garis-Garis Besar Haluan Negara (GBHN) dan diterjemahkan ke dalam Rencana Pembangunan Nasional. Untuk mengaplikasikan rencana ini, pemerintah merumuskannya ke dalam Pembangunan Lima Tahun (Pelita) I sampai V. Meskipun pengembangan industri pariwisata telah dirancang secara terencana sejak tahun 1960-an, undang-undang yang mengatur secara khusus tentang kepariwisataan baru dikeluarkan pada tahun 1990 melalui Undang-Undang No. 9 tahun 1990. Ini terjadi karena, pada saat itu kebijakan politik pemerintah menempatkan industri pariwisata sebagai sektor utama untuk meningkatkan devisa negara dan pertumbuhan ekonomi.

Meski telah direncanakan dan dilaksanakan sejak tahun 1960-an, dampak industri pariwisata bagi pembangunan nasional belum menunjukkan hasil signifikan. Alasannya adalah persepsi masyarakat Indonesia yang melihat pariwisata secara negatif. Pariwisata cenderung diasosiasikan dengan aktivitas yang melanggar norma-norma kesusilaan dan merusak kebudayaan. Banyak tokoh agama dan pemuka masyarakat tidak berpihak kepada pembangunan pariwisata karena persepsi demikian. Ditambah lagi, informasi yang utuh tentang pariwisata masih sangat terbatas diterima oleh masyarakat. Alasan lainnya adalah, kehadiran industri pariwisata di masa-masa awal yang cenderung berorientasi pada penerimaan devisa negara menyebabkan masyarakat merasa tidak mendapatkan manfaat secara riil.

Dalam perkembangannya, kepariwisataan Indonesia dibenahi. Pembenahan dimulai dengan melakukan reorientasi arah pengembangan industri pariwisata dari yang sebelumnya hanya berfokus untuk menghasilkan devisa bagi negara, kemudian diperluas untuk meningkatkan kesejahteraan dan mempersiapkan lapangan kerja untuk masyarakat. Dengan memperluas fokus industri pariwisata ini, UU No. 9 tahun 1990 tentang Kepariwisataan yang tidak mempertimbangkan aspek manfaat riil untuk masyarakat kemudian direvisi, lalu melahirkan UU No. 10 tahun 2009. Orientasi ini pun diperkuat dalam dokumen Rencana Pembangunan Jangka Panjang (RPJP) 2005-2025 yang menyebut kepariwisataan sebagai salah satu ujung tombak perluasan kesempatan kerja dan peningkatan kesejahteraan masyarakat [5].

Persepsi negatif masyarakat tentang pariwisata perlahan berubah karena sosialisasi yang terus dilakukan dan penyebaran informasi yang utuh tentang pariwisata. Manfaat riil seperti lapangan pekerjaan turut mempengaruhi persepsi masyarakat luas. Pergeseran paradigma tentang pariwisata dari yang hanya sebagai industri menjadi instrumen untuk peningkatan 
kualitas hidup manusia secara holistik benar-benar mengubah pandangan masyarakat tentang pariwisata hari ini. Paradigma baru ini yang biasa disebut dengan pariwisata berkelanjutan.

Manfaat industri pariwisata bagi pembangunan nasional menunjukkan hasil signifikan sejak tahun 2015. Sejak itu, pemerintah Indonesia menjadikan pariwisata sebagai leading sector pertumbuhan ekonomi dan pemerataan pembangunan [13]. Untuk mencapai tujuan ini, pengembangan pariwisata dilakukan melalui pemetaan pelanggan/wisatawan dan penentuan jenis destinasi wisata; penyediaan akses baik akses data, akses pembiayaan, maupun akses/konektivitas antardaerah; dan perkuatan amenitas mendukung kebutuhan wisatawan di daerah wisata. Strategi pengembangan ini melibatkan banyak aktor, yaitu akademisi sebagai konseptor, pemerintah sebagai regulator, swasta sebagai eksekutor, media sebagai pengontrol, dan komunitas masyarakat sebagai akselerator. Strategi dan kolaborasi ini menghasilkan percepatan pembangunan sektor pariwisata hanya dalam waktu singkat. Indonesia menurut World Travel and Tourism Council (WTTC) berada di peringkat 9 dunia dalam hal perkembangan pariwisatanya. Bahkan untuk Asia Tenggara, Indonesia sebagai negara yang paling cepat pertumbuhan pariwisatanya. Sejak 2018, sektor pariwisata menempati urutan pertama dalam menyumbang devisa bagi negara, setelah pada tahun 2015 menempati urutan ke empat (lihat Gambar 3). Berikutnya adalah satu aspek yang menarik untuk dikaji terkait kepariwisataan ini, yaitu pengembangan wisata kota yang menjadi tren di Indonesia. Tren baru ini bisa memberikan dampak bagi pola urbanisasi yang terjadi di Indonesia kedepannya.

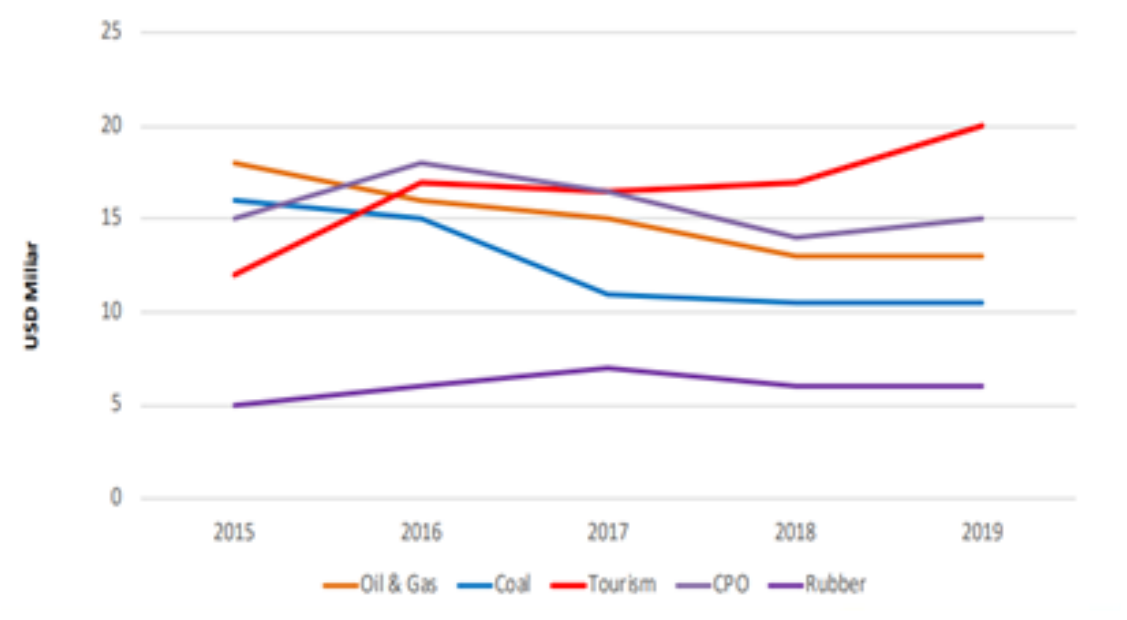

Gambar 3. Penerimaan devisa negara dari berbagai sektor [14].

\subsection{Pengembangan wisata kota}

Wisata kota atau urban tourism mulai dikembangkan di Eropa pada tahun 1980-an. Pengembangan wisata kota ini dilatari oleh dua kondisi yang dialami kota-kota di Eropa ketika itu. Pertama, berkembangnya kota-kota industri baru di Eropa mengakibatkan terjadinya deindustrialisasi pada kota-kota tua di sana. Deindustrialisasi ini menyebabkan hilangnya pekerjaan di bidang manufaktur pada kota-kota tua ini. Masalah sosial seperti pengangguran muncul. Selain itu, banyak situs-situs di dalam kota yang terlantar. Karena ditinggalkan industri 
manufaktur, kota-kota tua ini mencari industri pengganti yang dapat memanfaatkan situssitus lama ini dan bisa menciptakan kembali lapangan pekerjaan. Kedua, kebuntuan kota-kota tua ini dalam mengembangkan ekonomi kotanya dijawab dengan semakin berkembangnya kepariwisataan [15]. Untuk Indonesia, perkembangan kepariwisataan ini baru dirasakan memasuki tahun 1990-an seperti yang telah diulas dalam sub bab sebelumnya.

Sejak tahun 1980-an, wisata kota secara perlahan berkembang, kemudian mempengaruhi negara-negara lain di luar Eropa untuk mengembangkan wisata kota sebagai sektor industri yang mendatangkan manfaat ekonomi kotanya. Di Indonesia, wisata kota mulai menjadi tren sejak memasuki dekade kedua abad ke-21. Berbeda dengan latar berkembangnya wisata kota di Eropa, Indonesia memiliki kekhasannya tersendiri yang dipengaruhi oleh latar sejarah masa lampau dan karakteristik budaya dan alam. Dari aspek sejarah, Indonesia merupakan negara bekas kolonialisme yang hingga saat ini masih mempunyai jejak-jejak fisik di daerah perkotaan. Kota-kota besar di Indonesia saat ini memiliki jejak kolonialisme di masa lampau, dan bahkan sisa-sisa pembangunan di masa penjajahan kini menjadi landmark kota hari ini. Kota tua seperti di Jakarta atau kota lama seperti di Semarang adalah contoh-contoh peninggalan bangsa Eropa yang dapat dijadikan wisata kota. Namun, Indonesia dengan sejarah masa lampau yang panjang tidak hanya berkaitan dengan kolonialisme. Sebelum masa kolonialisme, wilayah yang saat ini menjadi bagian dari Indonesia merupakan daerah kekuasaan kerajaankerajaan. Berbeda dengan masa kolonialisme yang banyak membangun kota-kota pesisir untuk alasan perdagangan, kota-kota pada jaman kerajaan berada pada wilayah yang agak jauh dari pesisir. Kota-kota di pedalaman ini memiliki corak yang lebih sakral dengan nilai-nilai tertentu sebagai unsur pembangunan kotanya. Kota-kota itu kini ada yang masih eksis, namun tidak berkembang seperti halnya kota-kota besar. Kota-kota kecil dan sedang itu memiliki kekhasan pada aspek atraksi kebudayaan dan landmark kota yang khas pula. Contoh kota seperti ini adalah Yogyakarta, Surakarta, dan Manado.

Selain kesejarahan, latar pembentuk munculnya wisata kota di Indonesia dipengaruhi oleh budaya dan alam. Pluralisme budaya di Indonesia merupakan sebuah keunggulan yang menjadi karakteristik dalam mengembangkan kota wisata. Produk-produk budaya, baik berupa atraksi, ritual, maupun bentuk fisik dapat menjadi daya tarik wisata pada kota-kota kecil dan sedang di Indonesia. Selain itu, keindahan alam juga menjadi unsur terbentuknya kota wisata di Indonesia. Daerah-daerah yang memiliki pesona alam yang indah akan turut membentuk daerah urban baru pada pusat-pusat aktivitas manusianya. Karena daya tarik alam di suatu daerah, kotanya dapat menjadi pusat aktivitas kepariwisataan. Kota-kota baru ini juga bisa dikembangkan menjadi kota wisata sebagai penopang kepariwisataan alam yang merupakan keutamaan pada daerah tersebut. Hal yang bisa dilakukan untuk mengembangkan kota-kota baru ini sebagai kota wisata adalah melalui aktivitas kuliner yang menampilkan makanan khas daerah. Atau juga menampilkan kebudayaan daerahnya sebagai daya tarik tambahan pada kota baru ini. Dibandingkan dengan pengembangan kota wisata di Eropa, Indonesia memiliki lebih banyak alternatif untuk menjadikan kotanya sebagai kota wisata. Tren wisata kota menjadi salah satu sektor pembangunan yang memberi dampak terhadap pola baru urbanisasi di Indonesia. 


\subsection{Menjawab kebuntuan urbanisasi}

Masalah urbanisasi hari ini berupa sebuah paradoks yang diciptakannya sendiri. Di satu sisi, urbanisasi di Indonesia berhasil meningkatkan pertumbuhan ekonomi dan kesejahteraan masyarakat secara makro. Namun di sisi lain, urbanisasi justru menjadi penyebab terjadinya kesenjangan ekonomi antara masyarakat perkotaan dan perdesaan. Demikian juga halnya dengan urbanisasi yang tidak proporsional karena terkonsentrasi penduduk hanya di kotakota besar menciptakan ketimpangan yang tinggi antar wilayah di Indonesia. Selain itu, masih banyaknya masyarakat miskin kota dan berkembangnya kawasan kumuh menjadi indikator lain kegagalan urbanisasi.

Pengembangan kepariwisataan Indonesia memberi jawaban atas kebuntuan urbanisasi hari ini, kemudian menginisiasi perjalanan urbanisasi di Indonesia kedepannya. Jawaban atas kebuntuan urbanisasi hari ini ditelaah dari pergeseran paradigma kepariwisataan, strategi pengembangan pariwisata, dan pola pengelolaan kepariwisataan.

Trayektori kepariwisataan Indonesia menunjukkan adanya tren positif dalam agenda pembangunan nasional. Perkembangan positif ini tidak terlepas dari pergeseran paradigma dan strategi pengembangan pariwisata. Dari aspek paradigma, menempatkan pariwisata sebagai industri semata menjadikan kepariwisataan sebagai hal yang ekslusif dimiliki oleh orang yang memiliki modal dan penguasa. Sedangkan, masyarakat hanya menjadi obyek yang dilibatkan untuk kepentingan penguasa (penerimaan devisa) dan pemodal (keuntungan ekonomi). Pertumbuhan ekonomi yang terjadi adalah pertumbuhan dalam tataran makro, sementara manfaat riil yang dirasakan oleh masyarakat, tidak tercapai. Paradigma inilah yang menjadikan pariwisata Indonesia di tahun 1960-an sampai 1990-an tidak berkembang signifikan, selain alasan persepsi masyarakat tentang pariwisata. Memasuki abad ke-21, wacana pembangunan berkelanjutan (sustainable development) yang menjadi fokus negaranegara di dunia turut mempengaruhi paradigma kepariwisataan. Pariwisata tidak lagi dilihat hanya sebagai industri yang berorientasi pada keuntungan ekonomi, tetapi mencakup peningkatan kualitas manusia secara holistik. Dengan paradigma baru ini, pariwisata menjadi instrumen yang mewujudkan pemenuhan kebutuhan ekonomi, sosial, dan kelestarian lingkungan secara bersamaan. Sifatnya menjadi inklusif dengan peran masyarakat sebagai subyek yang memberdayakan dirinya sendiri melalui pariwisata.

Karena pergeseran paradigma ini, strategi pengembangan pariwisata pun ikut berubah. Pemerintah dan swasta tidak lagi dominan dalam mengembangkan sektor pariwisata. Keterlibatan para akademisi, komunitas masyarakat, dan media massa sangat penting untuk memastikan kemanfaatan pariwisata secara holistik. Pemerintah dengan fungsinya sebagai pengatur tidak bisa dominan dalam mengarahkan pariwisata hanya menguntungkan aspek makro, begitu pun pihak swasta tidak bisa sebebasnya mengambil keuntungan dari pariwisata tanpa memperhatikan batasan-batasan daya dukung alam dan keterlibatan masyarakat setempat. Masyarakat menjadi lebih leluasa untuk mendatangkan manfaat ekonomi dan sosial dari aktivitas pariwisata. Untuk memastikan pengembangan pariwisata yang berkelanjutan, akademisi dan media massa memiliki peran yang urgen. Akademisi melakukan 
kajian dan perencanaan dan media massa melakukan kontrol agar aktivitas kepariwisataan lebih berkeadilan.

Pariwisata menciptakan pertumbuhan ekonomi dan pemerataan pembangunan di Indonesia. Satu wujud konkretnya hari ini adalah munculnya pariwisata perdesaan yang model pengelolaannya dilakukan melalui pariwisata berbasis komunitas (community based tourism). Berkembangnya model kepariwisataan desa ini diidentifikasi melalui dua hal. Pertama, wacana pembangunan berkelanjutan yang menempatkan orientasi sosial dan kelestarian lingkungan sama pentingnya dengan orientasi ekonomi dalam pembangunan. Desa sebagai permukiman memiliki warisan nilai-nilai sosial yang masih terjaga dengan baik. Selain itu, desa masih mempertahankan lingkungan alamnya yang tidak tersentuh oleh dampak negatif modernisasi. Dengan dua kondisi ini, desa menjadi role model dan memiliki posisi tawar penting dalam agenda paradigma pembangunan berkelanjutan. Kedua, paradigma pembangunan berkelanjutan turut mempengaruhi preferensi masyarakat global dalam bidang pariwisata. Saat ini, berkembang tren pariwisata dunia yang mengarah kepada demasifikasi atau fragmentasi pasar. Tren ini disebabkan oleh bergesernya preferensi wisatawan untuk memilih produk-produk wisata yang menekankan unsur pengalaman, keunikan, dan kualitas. Desa memiliki semuanya itu, keunikan pengalaman sosial-budaya dan keindahan alam yang masih terjaga. Dengan adanya tren demikian, peluang peningkatan ekonomi masyarakat menjadi besar dan pemerataan pembangunan dapat terwujud, karena masyarakat menjadi aktor utama dalam mengembangkan pariwisata di desa. Dua contoh wisata perdesaan yang saat ini berkembang di Indonesia adalah Desa Wisata Pentingsari (Yogyakarta) dan Desa Wisata Nyegara Gunung (Bali).

Melalui pengelolaan kepariwisataan desa berbasis komunitas, desa menjadi locus bertumbuhnya faktor produksi dan peluang usaha yang sepenuhnya dikelola oleh masyarakat. Lapangan-lapangan pekerjaan mulai bertumbuh di desa. Tenaga kerja terampil yang dimiliki oleh desa dapat mengisi lapangan pekerjaan ini. Dengan demikian, manfaat ekonomi secara langsung dirasakan oleh masyarakat. Jika 74 ribu desa di Indonesia yang memiliki keunikan lanskap dan budaya masing-masing memanfaatkannya untuk kepariwisataan desa, dampaknya akan sangat signifikan bagi pemerataan pembangunan. Sehingga, di satu sisi migrasi desa ke kota akan menurun dengan signifikan, di sisi lain infrastruktur ekonomi dan suprastruktur sosial-budaya daerah perdesaan akan terbangun dan menunjukkan ciri-ciri perkotaan.

Selain itu, berkembangnya tren wisata kota di Indonesia dapat berkontribusi terhadap tumbuhnya pusat-pusat ekonomi baru di Indonesia. Pengembangan wisata kota yang menjadikannya sebagai pusat-pusat ekonomi baru di Indonesia dapat dilakukan melalui kemitraan publik dan swasta. Sektor publik yaitu pemerintah setempat memiliki peran kunci dalam mengembangkan strategi pariwisata, menyediakan dan mengelola ruang terbuka publik, membangun dan memelihara produk budaya dan alam untuk meningkatkan daya tarik wisatawan (seperti landmark kota, museum, atraksi budaya, dan sebagainya). Sedangkan sektor swasta memiliki peran dalam manajemen dan pemasaran pariwisata. Kemitraan publik 
dan swasta dalam mengembangkan wisata kota berimplikasi terhadap perkembangan infrastruktur ekonomi dan suprastruktur sosial-budaya kota-kota tersebut. Kota kecil, sedang, bahkan daerah urban baru yang mengembangkan wisata kota akan menjadi pusat ekonomi aglomerasi baru yang memungkinkan pertumbuhan ekonomi dan peningkatan kesejahteraan masyarakat di sekitarnya. Konsentrasi penduduk tidak lagi hanya terjadi di kota-kota besar, tetapi juga menyasar pada daerah-daerah pertumbuhan ekonomi baru dari aktivitas pariwisata. Migrasi dari desa ke kota akan menyasar daerah-daerah baru ini, sehingga meminimalisir migrasi masuk ke kota-kota besar di Indonesia.

Pengembangan kepariwisataan akan menginisiasi agenda urbanisasi di Indonesia kedepannya. Urbanisasi sebagai faktor pendorong terjadinya peningkatan ekonomi dan kesejahteraan masyarakat menggunakan dua pola. Pertama, melalui kehadiran pariwisata, urbanisasi di Indonesia akan mengalami pergeseran dari coraknya yang didominasi oleh migrasi desa ke kota menjadi urbanisasi yang berorientasi pada pengembangan wilayah desa sehingga memiliki ciri perkotaan. Kedua, pariwisata melalui pengembangan wisata kota akan menjadikan kota-kota kecil, sedang, dan daerah urban baru yang memiliki daya tarik wisata mengalami peningkatan urbanisasi yang ditandai oleh perkembangan infrastruktur ekonomi sebagai penopang aktivitas wisata. Dengan kedua pola ini, urbanisasi di Indonesia akan terjadi secara proporsional dan berkontribusi terhadap agenda pemerataan pembangunan di Indonesia.

\section{Kesimpulan}

Pembangunan dan urbanisasi merupakan proses yang terjadi terus-menerus, keduanya selalu berjalan beriringan dan mempengaruhi satu sama lain. Pada satu sisi, pembangunan memicu terjadinya urbanisasi pada suatu daerah sehingga menjadikannya berkembang dari waktu ke waktu. Pada sisi lain, perkembangan daerah tersebut menciptakan kompleksitasnya kebutuhan pembangunan, sehingga urbanisasi terus berlangsung pada daerah tersebut.

Kepariwisataan sebagai salah satu instrumen pembangunan dan urbanisasi adalah perpaduan yang relatif baru dalam diskursus pembangunan; setidaknya itu yang terjadi di Indonesia. Pertautan antara keduanya menghasilkan pola baru dalam urbanisasi sekaligus memberi jawaban atas tantangan pemerataan pembangunan. Hal ini tidak terlepas dari karakteristik kepariwisataan sebagai sektor pembangunan yang inklusif. Daerah-daerah yang memiliki potensi besar di bidang pariwisata menjadi pusat-pusat aktivitas ekonomi, politik, sosialbudaya, dan modernisasi. Urbanisasi berlangsung seiring berkembangnya daerah-daerah tersebut sebagai pusat aktivitas manusia. Maka pola urbanisasi yang terjadi di Indonesia mulai berubah, tidak lagi hanya terkonsentrasi pada kota-kota besar yang merupakan pusat industrialisasi, melainkan berkembang dan menyebar ke daerah-daerah pariwisata. Wisata pedesaan dan wisata kota adalah dua hal yang dibahas secara mendalam dalam penelitian memicu terjadinya perubahan pola urbanisasi di Indonesia.

Penelitian tentang urbanisasi yang dipicu oleh pariwisata penting untuk dilakukan di Indonesia kedepannya, mengingat kepariwisataan menjadi leading sector pembangunan di Indonesia dalam beberapa tahun terakhir. Penelitian-penelitian serupa telah banyak dilakukan di negara 
lain, seperti di Australia yang dilakukan oleh Mullins [16] terhadap Kota Gold Coast dan Sunshine Coast serta Kota Zhapo di China yang dilakukan oleh Junxi Qian, Dan Feng, Hong dan Zhu [17]. Kedua penelitian ini sama-sama mengafirmasi tesis tentang urbanisasi pariwisata (tourism urbanization) sebagai penciptaan ruang-ruang konsumsi pada kota (kota yang dibangun untuk tujuan kesenangan). Namun, terdapat perbedaan dalam satu hal dari kedua penelitian ini. Mullins melihat urbanisasi pariwasta pada Kota Gold Coast dan Sunshine Coast adalah produk dari post-modern, sementara urbanisasi pariwisata Kota Zhapo dibentuk oleh modernisasi di China. Penelitian tentang urbanisasi pariwisata untuk kota-kota baru di Indonesia ke depan bertujuan untuk menelaah karakteristik tertentu dari bentuk urbanisasi pariwisata tersebut, dan diharapkan memberikan sumbangan besar bagi dinamika urbanisasi dan wacana pemerataan pembangunan di Indonesia.

\section{Referensi}

[1] Bolt J, Inklaar R, Jong $H$ de, Zanden JL van. Rebasing 'Maddison': New Income Comparisons And The Shape of Long-Run Economic Development. 2018.

[2] Roberts M, Sander FG, Tiwari S. Time to ACT: Realizing Indonesia's Urban Potential. Washington: World Bank Group; 2019. https://doi.org/10.1596/9781464813894.

[3] Badan Pusat Statistik. Pertumbuhan Ekonomi Indonesia Triwulan IV-2019. Badan Pus Stat 2020:12.

[4] Malau W. Dampak Urbanisasi Terhadap Pemukiman Kumuh (Slum Area) di Daerah Perkotaan. JUPIIS J Pendidik Ilmu-IImu Sos 2013;5:39-47. https://doi.org/10.24114/jupiis.v5i2.1113.g872.

[5] Ardika IG. Kepariwisataan Berkelanjutan: Rintis Jalan Lewat Komunitas. Jakarta: Penerbit Buku Kompas; 2018.

[6] Sugiyono. Metode Penelitian Kuantitatif Kualitatif dan R\&D. Bandung: Penerbit Alfabeta; 2019.

[7] Keban Y. Urbanisasi-Konsep, Teori, dan Kebijakan 1995.

[8] Harahap FR. Dampak Urbanisasi Bagi Perkembangan Kota di Indonesia. J Soc 2013;1:3545. https://doi.org/10.33019/society.v1i1.40.

[9] Damsar, Indrayani. Pengantar Sosiologi Perkotaan. Jakarta: PT. Kharisma Putra Utama; 2017.

[10] Wheatley P. Nagara and Commandery: Origins of The Southeast Asian Urban Tradition. Chicago: University of Chicago; 1983.

[11] Kuswartojo T. Kaca Benggala: Perkembangan Habitat Manusia di Indonesia. Bandung: Ukara Lawang Buwana; 2019.

[12] Statistik BP. Jakarta Dalam Angka 2018. Jakarta: Badan Pusat Statistik Provinsi DKI Jakarta; 2018.

[13] Kementerian Pariwisata dan Ekonomi Kreatif RI. Laporan Kinerja Kementerian Pariwisata Tahun 2018. Jakarta: Kementerian Pariwisata dan Ekonomi Kreatif RI; 2019.

[14] Thaib HS. Strategi Pengembangan Kepariwisataan Indonesia 2019.

[15] Law CM. Urban Tourism and its Contribution to Economic Resurgence. Urban Stud 1992;29:599-618. https://doi.org/10.1080/00420989220080581.

[16] Mullins P. Class Relations and Tourism Urbanization: The Regeneration of the Petite 
Bourgeoisie and the Emergence of a New Urban Form. Int J Urban Reg Res 1994;18:591-608. https://doi.org/10.1111/j.1468-2427.1994.tb00288.x.

[17] Qian J, Feng D, Zhu H. Tourism-Driven Urbanization in China's Small Town Development: A Case Study of Zhapo Town, 1986-2003. Habitat Int 2012;36:152-60. https://doi.org/10.1016/j.habitatint.2011.06.012. 